KONSELING: Jurnal Ilmiah Bimbingan dan Konseling

Vol.1, No.1, Oktober 2019, pp. 41-48

e-ISSN: 2686-2875

https://journal.ilininstitute.com/konseling

DOI: $10.31960 /$ konseling.v1i1.339

Received on 05/09/2019; Revised on 20/09/2019; Accepted on 13/10/2019; Published on:28/10/2019

\title{
Self Control dalam Meningkatkan Konsistensi Belajar Akademik
}

\author{
Muhammad Fadhil Alghi Fari Majid ${ }^{1 *}$, Mulkul Farisa Nalva ${ }^{2}$, Baharuddin $^{3}$ \\ ${ }^{123}$ Pendidikan Agama Islam, UIN Sunan Kalijaga Yogyakarta, Indonesia \\ ${ }^{*}$ Correspondence Email: fadhil.ghifari123@gmail.com
}

\begin{abstract}
Abstrak: Tujuan dalam penelitian ini yaitu bagaimana self control dapat meningkatkan konsistnsi belajar akademik. Metode penelitian yang digunakan yaitu metode penelitian kualitatif dengan jenis penelitian (Field Research) atau penelitian lapangan, pengempulan data melalui triagulasi data (observasi, wawancara, dan dokumentasi). Adapun hasil penelitian yang diperoleh bahwa konsistensi belajar setiap individu sangat didasari pada motivasi belajar yang baik, apabila seseorang memiliki motivasi belajar yang cenderung baik, akan selalu timbul semangat belajar dari dalam dirinya sebagai kebutuhan dalam belajar untuk mencapai tujuan pembelajaran. Oleh karena itu, selfcontrol suatu sifat yang harus disadari agar timbul motivasi belajar sehingga dapat meningkatkan konsisten belajar pada siswa/mahasiswa. Jadi self control dapat menggerakkan seseorang dalam melakukan hal-hal positif termasuk konsisten dalam belajar karena adanya kontrol diri, dapat dikatakan bahwa semikin baik self control maka semakin konsisten individu dalam belajar.
\end{abstract}

Kata Kunci : self control, konsistensi bekajar, Akademik.

\begin{abstract}
The purpose of this study is how self control can improve academic learning consistency. The research method used is qualitative research methods with the type of research (Field Research) or field research, data collection through data triagulation (Interview observation, and documentation). The research results obtained that the consistency of learning of each individual is based on good learning motivation, if someone has a learning motivation that tends to be good, there will always be a spirit of learning from within themselves as a need in learning to achieve learning goals. Therefore, self-control is a trait that must be realized in order to arise motivation to learn so as to increase consistent learning in students/students. So self control can move a person to do positive things including being consistent in learning because of self control, it can be said that the better the self control, the more consistent the individual is in learning.
\end{abstract}

Keywords: self control, consistent learning, Academic.

This is an open access article distributed under the Creative Commons Attribution License, which permits unrestricted use, distribution, and reproduction in any medium, provided the original work is properly cited. (C2019 by author.

\section{Pendahuluan}

Konsisten terhadap diri sendiri tidak mudah seperti yang diucapkan, naik turunnya konsistensi pada individu seringkali menjadi problematika dalam kehidupan, khususnya dalam belajar. Konsistensi diri merupakan salah satu bagian dari aspek keperibadian individu. Aspek keperibadian seseorang dapat berupa kepercayaan, tindakan maupun sikap (Mahmud, 2010: 98). Maka dari itu dalam menyikapi arus globalisasi, diperlukan peningkatan belajar secara konsisten. Salah satu problem yang sering kali ditemui adalah semangat belajar yang tidak konsisten. Konsistensi belajar merupakan sesuatu permasalahan dalam dunia akademisi. Oleh karena itu, 
dibutuhkan suatu usaha sadar yang dilakukan oleh individu itu sendiri dalam meningkatkan konsistensi belajar sesuai ketentuan akademik melalui Self control atau pengontrolan diri sendiri.

Proses belajar tidak terlepas dari kata peserta didik, karena peserta didik merupakan objek utama dalam proses pembelajaran. Akan tetapi, peserta didik yang menempu pendidikan di era ini sudah sangat jauh berbeda pada masa sebelumnya, banyak sekali faktor yang membuat peserta didik itu mengalami penurunan prestasi belajar salah satunya karena motivasi belajar yang rendah atau tidak adanya konsisten dalam pembelajaran. Oleh karena itu, peserta didik yang memiliki konsistensi belajar yang tidak stabil akan menghasilkan prestasi belajar yang tidak memuaskan, begitu juga sebaliknya, ketika peserta didik memiliki konsistensi belajar yang stabil, maka prestasi belajarnya akan lebih memuaskan. Munurut Khalsa, siswa yang memiliki prestasi rendah dari pada semestinya akan memperlihatkan tingkah laku negatif dan menyebabkan kehancuran terhadap konsep diri (keperibadian) dalam jangka waktu bertahun-tahun (Khalsa, 2008:64).

Pesatnya perkembangan pendidikan terkadang membuat manusia terlena akan kecanggihan teknologi, baik dikalangan anak-anak, remaja, maupun orang dewasa. Kecanggihan teknologi yang seharusnya digunakan dalam hal-hal positif sering kali tidak sesuai dengan fungsinya, misalanya munculnya persepsi bahwa dunia game lebih menarik dibandingkan dunia belajar. Munculnya problem ini sangat memungkinkan turunya minat belajar. Turunya minat belajar sesorang akan sulit untuk membangun komitmen atau prinsip dalam belajar secara efektif. (Lilik Suyanti, 2012: 67). Dalam membentengi konsistensi belajar seseorang, menurut hemat penulis adalah perwujudan kontrol terhadap diri sendiri (Self control).

Berdasarkan problematika di atas, menjadi dasar pemikiran dalam penelitian ini bahwasanya penulis akan mengungkap secara detail terkait dengan "Self control dan Self Consciousness dalam Meningkatkan Konsitensi Belajar Akademik Mahasiswa PAI Program Magister UIN Sunan Kalijaga".

\section{Metode}

Metode penelitian yang digunakan dalam penelitian ini yaitu metode penelitian kualitatif. Metode penelitian kualitatif dengan menggunkan jenis penelitian (Field Research) atau penelitian lapangan . Metode penelitian kualitatif berguna untuk memperoleh data yang mendalam dan mengandung makna sesuai yang terjadi dilapangan. Oleh sebab itu, dalam penelitian kualitatif tidak menekankan pada generalisasi, akan tetapi lebih menekankan pada makna yang terkandung di dalamnya (Sugiyono, 2017: 15) Langkah utama dalam penelitian dapat dilihat dari teknik pengumpulan data yang dilakukan. Maka dari itu, pengempulan data yang dilakukan oleh penulis yakni observasi (Pengamatan), Interview (Wawancara), dan dokumentasi.

Penelitian ini dilakukan di UIN Sunan Kalijaga Pada Program Magister Studi PAI. Adapun subyek dalam penelitian ini dengan melakukan wawancara kepada Mahasiswa Magister PAI Kelas A1 Angkatan 2019 UIN Sunan Kalijaga Yogyakarta. Peneliti juga melakukan observasi langsung pada Mahasiswa Magister PAI Kelas A1 Angkatan 2019 UIN Sunan Kalijaga Yogyakarta terkait self contol dalam konsistensi belajar akademik Mahasiswa. Dalam penelitian ini, peneliti juga melakukan triagulasi data dengan melakukan cross check data hasil wawancara, observasi dan dokumentasi sehingga data yang diperoleh lebih akurat.

\section{Hasil Dan Pembahasan}

\section{Konsistensi Belajar Akademik Mahasiswa PAI Program Magister}

Sikap konsistensi dapat dipahami bahwa adanya kesesuaian antara ucapan dan aktualisasi (Antonius Atosokhi Gea, 2006: 20). Pendapat ini menjelaskan bahwa Sikap konsistensi yang dimiliki oleh individu akan relevan dengan apa yang dilakukannya. Konsistensi adalah mempertahankan ekspektasi perilaku selaras dengan ketentuan yang sebenarnya (Evertson. dkk, 2011: 184). Konsistensi berarti kemampuan setiap individu dalam menyelaraskan perilaku dan sikapnya supaya terlihat rasional dan konsiten (Robbins, 2010: 41). Konsitensi dapat diartikan sebagai ketetapan hati (konsisten diri) yang mengacuh pada tujuan, kehendak, dan minat (Basten, 2010: 120). Konsitensi diri adalah kesanggupan untuk memelihara irama hati dan tingkah laku 
sehingga mampu secara berkelanjutan memberi perhatian terhadap sesuatu yang dianggap penting dalam proses tersebut (Nashori, 2011: 175).

Senada dengan teori di atas, hal yang sama diungkap oleh H.B selaku mahasiswa megister PAI, ketika diwawancari tentang bagaimana pandangannya tentang konsistensi belajar dalam lingkup akademik, dia mengatakan bahwa:

"konsistensi dalam balajar khususnya dalam lingkup akademik memang sangat penting untuk direalisasikan karena dengan adanya konsistensi belajar dalam diri menjadi modal utama dalam menghadapi pembelajaran yang telah ditentukan oleh pihak akademik".

Selain pandangan H.B, pertanyaan yang sama diajukan kepada Sukasmin yang juga merupakan Mahasiswa Program Magister PAI UIN Sunan Kalijaga. Adapun komentarnya sebagai berikut: "Konsistensi belajar dalam lingkup akademik menurut saya, hal yang harus di pahami oleh setiap Mahasiswa karena dalam lingkup akadamik sangat banyak tanggung jawab yang harus di penuhi seperti mata kuliah yang ditentukan oleh pihak akademik. Untuk menjaga structural pembelajaran maka harus dibarengi dengan konsistensi".

Dari pandangan Narasumber di atas, dapat dipahami bahwa konsistensi dalam belajar merupakan hal penting yang harus dipahami oleh setiap pelajar dan kemudian mampu untuk mengaktualisasikan dalam kehidupan sehari-hari demi tercapainya suatu kesuksesan baik secara ilmu pengetahuan maupun struktur akademik.

Tidak konsistennya seseorang dalam belajar biasnya menyebabkan kesulitan dalam proses pembelajaran. Kesulitan belajar adalah keadaan seseorang dengan kemampuan intelegensi yang rendah atau dibawah rata-rata, akan tetapi tidak memiliki kemampuan ataupun gagal dalam belajar yang berkaitan dengan kendala dalam proses konseptualisasi, berpendapat, berbahasa, serta pemusatan perhatian. Kesulitan-kesulitan seperti ini terkadang tidak diperhatiakan oleh orang tua ataupun guru, sehingga mengakibatkan seringya diidentifikasi selaku anak pemalas, underachiever, dan aneh. Dengan identifikasi itu membuat anak akan merasa frustasi, depresi, marah, dan merasa tidak dibutuhkan (Yulianda Erma Suryani, 2010: 34).

Suhubungan dengan teori di atas, untuk membuktikan kebenaranya, maka penulis melakaukan wawancara langsung dengan beberapa Narasumber yang pernah mengalami hal tersebut yakni tidak konsisten dalam belajar. Adapun Narasumber yang dimaksud yaitu W.B, selaku Mahasiswa Program Magister PAI UIN Sunan Kalijaga. Pertanyaan yang diberikan oleh peneliti adalah apakah anda pernah merasa kurang konsisten dalam belajar dan bagaiamana dampaknya. Komentarnya sebagai berikut:

"Betul, saya pernah dalam posisi itu. Proses belajar saya tergantun dari mood saya tanpa ada tekanan dari siapapun. Ternyata sikap tersebut berdampak negatif terhadap diri saya sendiri seperi menimbulkan kemalasan dan cuek terhadap proses pembelajaran, ketika diberikan tugas terkadang saya kerjakan dan terkadang juga tidak saya kerjakan. Selain menyebabkan negatif terhadap pribadi saya, juga menyebabkan nilai akademik saya kurang baik".

Dari ungkapan W.B tersebut menggambarkan bahwasanya kurangnya konsistensi dalam belajar baik secara formal maupun non formal menyebabkan kemalasan dan apatis terhadap proses pembelajaran. Sehingga berdampak negatif terhadap diri sendiri maupun lingkup akademik. Selain W.B, hal yang serupa juga disampaikan oleh E.P dengan pertanyaan yang sama. Berikut ungkapannya: "Kuragnya konsistensi dalam belajar merupakan hal yang sering kali saya rasakan. Kurangnya konsistensi membuat saya melalaikan tanggung jawab di Kampus seperti timbulnya rasa malas mengerjakan tugas kampus, meminta teman untuk mengerjakan tugas mata kuliah, munculnya pikiran bahwa tugas mata kuliah adalah hal yang menakutkan, serta munculnya kemalasan untuk mengikuti mata kuliah".

Dari penjelasan E.P, dapat dipahami bahwa kurangnya konsistensi belajar yang dimiliki membuat dirinya malas untuk memenuhi tugas akademik baik berupa tugas mata kuliah maupun rasa malas untuk mengikuti jam mata kuliah. Adapun fakta yang diungkap oleh narasumber lain yang bernama F.Z, ketika diwawancarai mengenai problem yang di hadapi terkait konsistensi belajar, dia mengatakan bahwa: "konsistensi belajarnya seringkali tidak stabil, hal ini dapat dibuktikan karena kurangnya semangat dalam menyelesaikan tugas-tugas perkuliahan, sehingga banyak tugas yang tidak terselesaikan sebagai akibat tidak adanya konsistensi dalam belajar."

Berdasarkan informasi yang diungkapkan oleh ketiga Narasumber di atas dapat dianalisis bahwa konsistensi dalam beajar merupakan hal yang penting untuk dijadikan suatu prinsip dalam 
kehidupan manusia khususnya bagi pelajar ataupun Mahasiswa. Proses pembelajaran yang ditata secara terstruktur oleh pihak akademik sering kali membuat Mahasiswa sulit untuk mencerna dengan baik. Oleh karena itu, kesulitan seperti ini hanya mampu diatasi dengan konsistensi belajar. Kurangnya konsistensi dalam belajar akan memicuh timbulnya kemalasan dalam belajar, tidak memiliki rasa tanggungjawab terhadap proses belajar yang dihadapi, memicuh rasa malas untuk mengikuti jam pelajaran serta prestasi akadamik pun tidak sesuai dengan harapan manusia pada umumnya.

Banyak sekali faktor yang mempengaruhi seseorang tidak konsisten dalam belajar yaitu: pertama, faktor instrinsik, kesadaran yang timbul dari dalam diri seseorang unutk mencapai sutau keinginan dan tujuan yang dikehandakinya. Ketika tidak ada kesadaran dari dalam diri seseorang maka sulit akan mencapai suatu tujuan yang di inginkan. Kedua, faktor ekstkrinsik, motivasi belajar juga sangat didukung oleh orang-orang dekat dan lingkungan sekitar.

Berkaitan dengan pernyataan di atas maka dapat di tarik kesimpulan bahwa, konsistensi belajar setiap individu sangat di didasari dengan motivasi belajar yang baik, apabila seseorang memiliki motivasi belajar yang cenderung baik, sehingga akan selalu timbul semangat belajar dari dalam diri seseorang sebagai kebutuhan dalam belajar untuk mencapai suatu target atau tujuan belajar yang diinginkan. Dengan begitu seseorang akan mudah mengukir prestasi-prestasi belajar karena adanya motivasi dan konsistensi belajar.

Konsistensi belajar sangat membutuhkan motivasi belar. Oleh karena itu, motivasi adalah kegiatan yang dapat memberikan mendorong idividu untuk mengambil suatu tindakan ataupun keputusan yang dikehendaki untuk mencapai suatu tujuan yang telah direncakan. Sehingga dapat dikatakan bahwa konsistensi belajar adalah gejala psikologi yang dialamai seseorang sehingga mengalami penurunan motivasi dalam belajar, hingga akhirnya mengabaikan tugas-tugas akademiknya.

Berbagai macam problem yang dihadapi manusia dewasa ini merupakan hal yang cukup memperihatinkan. Oleh sebab itu, dibutuhkan solusi yang tepat untuk menghadapi problematika tersebut. Menurut penulis solusi yang dapat digunakan yaitu dengan Self control. Self control merupakan suatu usaha yang dilakukan oleh individu untuk memperbaiki tingkah laku yang dianggap negatif menuju tingkah laku yang posistif dengan cara mengontrol dirinya sendiri.

\section{Meningkatkan Konsistensi Belajar Akademik dengan Self control}

Kontrol diri atau Self control merupakan bentuk keadaan mental yang berpengaruh terhadap pembentukan tingkah laku . Terwujudnya tingkah laku yang positif, baik, dan produktif akan berdampak pada hubungan yang harmonis dengan orang lain. Hal demikian tidak terlepas dari pengaruh kemampuan kontrol diri (Self control). Kemampuan kontrol diri sangat berpengaruh terhadap kebiasaan belajar yang benar, tingkah laku yang tertib dimasyarakat dan disekolah, kedisiplinan dan tingkah laku seksual yang sehat. Dalam berdinamika di kehidupan dunia ini, self control menduduki posisi paling penting yang harus dipahami dan diaktualisasikan oleh manusia. Hal ini disebapkan dengan meningkatnya arus globalisasi yang menuntun manusia untuk tetap berada dalam koridor pengontrolan diri. Di era moderen ini, telah banyak kehidupan-kehidupan yang terkontaminasi dengan berbagai budaya yang kurang positif, salah satu diantaranya adalah kurangnya konsistensi dalam proses belajar. Maka dari itu, diperlukan self control yang dapat dijadikan sebagai penyaring dalam menghadapi problematika (Lilik Sriyanti, 2012: 68).

Gangguan dan kesulitan dalam tingkah laku banyak bersumber dari minimnya kontrol diri (Self control) ( Lilik Sriyanti, 2012: 68). Dalam buku Nur Gufron dan Rini Risnawati dijelaskan bahwa kontrol diri merupakan suatu kemapuan seseorang dalam kepekaan membaca keadaan diri dan linkungannya serta kecakapan mengendalikan dan mengolah faktor-faktor tingkah laku yang sesuai dengan kondisi untuk menampakan diri dalam bersosialisasi. Kemampuan dalam mengontrol tingkah laku cenderung memotivasi munculnya rasa peduli dan kemauan mengubah tingkah laku sesuai yang diinginkan (Nur Gufron dan Rini Risnawati,2011: 21-22)

Berhubungan dengan teori self control telah dikemukakan oleh para ahli terkait dengan pengontrolan diri, beberapa diantaranya (1) Self control adalah suatu kepercayaan individu bahwa untuk mencapi hasil-hasil yang diinginkan dapat melalui atas tindakan diri sendiri. Oleh karena itu, kontrol dan perasaan dapat berpengaruh terhadap situasi, akan tetapi anggapan kontrol diri 
tergantung dari kepribadian yang dimiliki orang tersebut, bukan dari situasi. Berdasarkan dari pendapat tersebut, seseorang beranggapan memiliki kontrol diri apabila orang tersebut mampu untuk mengetahui apa yang bisa dan apa yang tidak bisa di pengaruhi melalui tindakannya sendiri, dan apabila orang tersebut yakin akan kemampuannya akan menimbulkan perilaku yang sukses ( Bart.Smet, 1994: 38); (2) self control adalah kemampuan seseorang dalam proses pembinaan perilaku diri sendiri dengan artian perilaku implusif (Chaplin, 2008: 76); (3) self control adalah kemampuan unruk mengontrol diri sendiri dari emosi berlebihan yang mencolok. Hal tersebut dapat dilihat dengan gerak-gerik yang dilakukan seperti ketegangan seseorang apabila menghadapi stress atau kemampuannya mengontrol dirinya apabila ia dimusuhi oleh temannya (Daniel Goleman, 2005: 131). Dari penjelasan maka penulis menganalisis bahwa kontrol diri (Self Kontrol) merupakan salah satu hal yang dapat dijadikan sebagai media dalam meningkatkan motivasi dalam belajar sehingga dengan adanya motivasi tersebut memicuh peningkatan konsistensi dalam belajar. Self control pada dasarnya melatih mental manusia untuk mengendalikan apa yang difikirkan, dirasakan, diyakini, dan apa yang dilakukan (N. Ubaedi, 2005: 169).

Dalam proses pengontrolan diri ada beberapa hal yang perlu dilibatkan yaitu: pertama: kontrol perilaku, kesiapan individu dalam menanggapi rangsangan yang secara langsung apabila mendapatkan hal-hal yang tidak disenangi dan mencari solusinya. Kedua: Kontrol kognitif, kemampuan seseorang untuk mengola informasi-informasi yang tidak sesuai dengan keinginan, hal ini dapat dilakukan dengan memberikan penilaian atau merelevansikan kejadian dengan menguragi tekanan. Ketiga: Kontrol keputusan, kemampuan seseorang dalam memilih hasil sesuai apa yang dipercaya dan diyakini. (Nur Gufron dan Rini Risnawati, 2011: 31).

Sehubungan dengan beberapa pendapat di atas, untuk menguji kebenarannya suatu teori maka penulis melakukan wawancara langsung dengan beberapa Narasumber terkait dengan pandangannya terhadap proses meningkatakan konsistensi belajar melalui self control. Adapun narasumber yang diwawancarai oleh penulis yaitu K.N, selaku Mahasiswa Program Magister PAI UIN Sunan Kalijaga. Berikut penjelasanya: "Padangan saya ketika self control dijadikan sebagai media untuk meningkatkan konsistensi dalam belajar merupakan hal yang sudah tepat karena dengan adanya self control akan menjadi bahan penegur atau pengingat ketika hendak melakukan hal yang negatif".

Dari pandangan diatas dapat dipahami bahwa, self control adalah suatu kepercayaan setiap individu yang muncul dari dalam diri untuk melakukan sesuatu sehingga dapat memperoleh hasil sesuai dengan yang dikehendaki melalui tindakan dan dorongan dirinya sendiri tanpa ada pengaruh dari orang lain. Oleh karena itu, self control dapat memberikan pengaruh pada situasi ataupun keadaan seseorang. Akan tetapi, kontrol diri tergantung dari masing-masing individu, sesuai dengan tingkatan motivasi yang ada pada dirinya. Dengan adanya kontol diri terhadap individu sehingga mampu menfilter suatu tindakan yang ingin dilakukan sesuai dengan apa yang dikehendakinya dan dapat terhindar dari tindakan yang dapat merugikan dirinya.

Pendapat di atas dikuatkan dengan argumentasi oleh salah seorang narasumber dari mahasiswa Megister PAI yang bernama H.B tentang bagaimana pandangannya terhadap pentingnya proses dalam meningkatakan konsistensi belajar melalui self control. Dia menjelaskan bahwa: "saya menganggap bahwa self control merupakan suatu hal yang sangat penting yang harus di miliki oleh setiap individu terkhusus bagi saya yang menempu pendidikan, tanpa adanya self control yang saya lakukan terhadap diri saya maka akan terjadi sikap mengabaikan dalam malakukan sesuatu yang positif, termasuk dalam mengerjakan tugas kuliah dan akan menggatinya dengan kegiatan-kegiatan negative yang sangat merugikan dan menghambat dalam menyelesaikan perkuliahan tepat waktu".

Setelah mengamati ungkapan di atas, maka penulis dapat menyatakan bahwa kesuksesan akan mudah di capai oleh setiap individu ketika dalam dirinya selalu ada pertimbangan dalam melakukan sesuatu, adanya kontrol diri sehingga melakukan sesuatu sesuai dengan tujuan yang kehendaki. Memotivasi diri untuk selalu tergerak dalam melakukan kegiatan-kegiatan dalam pembelajaran.

Menyikapi kontrol diri, seringkali banyak orang yang mencampur adukkan dengan sikap keras, kaku, terhambat dan tegang. Anggapan seperti ini merupakan anggapan yang keliru, karena seseorang yang dapat mengendalikan dirinya juga sanggup untuk bersifat secara fleksibel. 
Sedangkan terhambat dan kaku bisa saja terlihat terkontrol, akan tetapi sangat mudah untuk dilupakan, tidak terkendali atau susah dalam mengontrol. Sesorang yang dapat mengontrol dirinya akan terlihat rileks dalam mengahadapi pergaulan dan mampu untuk beradaptasi dengan lingkungannya.

Menurut Hurlock, ada dua krakteristik dalam menentukan kontrol diri yaitu apakah kontrol emosi (self emotion) itu bisa diterima dilingkup sosial atau apakah kontrol emosi tersebut tidak bisa diterimah oleh masyarakat. Akan tetapi reaksi postif itu memerlukan penunjang kriteria yang lain seperti pengontrolan emosi pada keadaan fisik dan jiwa individu. Dengan mengontrol fisik dan jiwa seyogyanya tidak membahayakan kondisi fisik dan jiwa individu. Pengontrolan emosi ini diharapkan untuk mampu menjadikan pribadi seseorang menjadi lebih baik. (Hurlock, 1990: 122).

Selain menurut Hurlock, Buck juga berpendapat terkait dengan self control sebagaimana terdapat dalam buku Carlson mengatakan bahwa faktor internal merupakan faktor yang ada dalam setia diri individu yang berkembang secara unik. Maka dari pandangan tersebut, kontrol diri dikelompokkan menjadi tiga bagian yaitu: 1) hirarki dasar biologi yang sudah terstruktur dan tersusun berdasarkan evolusi. 2). Perkembangan self control biasanya dipengaruhi oleh bertambahnya usia individu tersebut. 3). Dalam teori kontrol diri dianggap dipengaruhi oleh emosional seseorang, seperti halnya emosi pada remaja (Carlson, 1987: 99).

Adapun langkah-langkah dalam membina self control pada diri individu dapat dilakukan dengan cara sebagai berikut: (1) Memperbaiki prilaku kearah yang positif, sehingga mampu menimbulkan kontrol diri yang positif dan meyakini bahwa itu adalah prioritas, (2) Melakukan proses pembinaan dengan mengstimulus keadaan internal pada diri sendiri sehingga memunculkan motivasi dalam diri sendiri, (3) Melakukan proses pembinaan dengan melatih kontrol diri dalam menghadapi kondisi-kondisi yang negatif. Artinya, sebelum melakukan sesuatu hal terlebih dahulu memperhatikan dampak yang akan ditimbulkan. (Michael Borba, 2008: 107-125).

Dari berbagai penjelasan teori self control di atas, dapat dipahami bahwa dalam meningkatkan konsistensi dalam belajar dapat dilakukan dengan pembinaan terhadap diri sendiri dengan melakukan pengontrolan. pengontrolan terhadap diri sendiri untuk meningkatkan konsistensi belajar dapat dilakukan dengan menanamkan prinsip dalam diri bahwa konsistensi belajar adalah prioritas, menanamkan kesadaran diri bahwa konsistensi belajar yang negatif merupakan hal yang keliru dan harus direkonstruksi kearah yang posistif, menghindari pergaulan negatif yang dapat memicuh terhambatnya suatu konsistensi, serta bersungguh-sungguh meninggalkan kebiasaan lama yang sifatnya negatif.

Sehubungan dengan hal tersebut penulis melakukan wawancara kembali dengan beberapa Narasumber sebelumnya seperti W.B, E.P dan F.Z selaku perwakilan informan yang memiliki konsitensi belajar yang tidak stabil. Sebagaimana informan tersebut telah dibahas di sub pembahasan sebelumnya selaku mahasiwa yang kurang konsistensi dalam belajar. Adapun pertanyaan peneliti adalah solusi apa yang digunakan dalam meningkatkan konsistensi belajar yang tidak stabil. Berikut penjelasan W.B tentang solusi yang digunakan dalam meningkatkan konsistensi belajarnya:

"soslusi yang saya gunakan dalam meningkatkan konsistensi belajar adalah pertama: memunculkan kesadaran diri bahwa saya harus berubah. kedua: kebiasaan buruk seperti lebih mementingkan game perlahan-lahan saya tinggalkan. Ketiga: Meminimalisir ajakan teman untuk kumpul malam dan menggatinya dengan hal positif seperti membaca buku".

Dari pendapat W.B tersebut dapat dipahami bahwa tindakan yang dilakukan merupakan bagaian dari pengontrolan diri sendiri (Self control). Sehingga penulis juga beranggapan bahwa solusi yang digunakan oleh W.B dalam meningkatkan konsistensi belajarnya adalah dengan self control. Sehubungan dengan argumen W.B, hal yang serupa diuangkapkan oleh E.P tentang solusi yang digunkan dalam meningkatkan konsistensi belajarnya kearah yang positif yaitu: "Dalam meningkatkan konsistensi belajar saya, terlebih dahulu saya mengoreksi faktor-faktor yang menyebabkan saya kurang konsistensi dalam belajar. kemudian dengan faktor tersebut saya mencoba untuk mengubah dengan meninggalkan kebiasaan buruk saya dengan mengontrol tindakan yang dapat menjerumuskan ke hal yang negative tersebut". 
Pendapat E.P tersebut dapat dipahami bahwa self control dijadikan solusi untuk mengubah kebiasaan buruknya dalam belajar menuju ke hal yang positif sehingga dianggap dapat memicuh konsistensi belajar dalam dirinya.

Begitu pula hal yang sama disampaikan oleh F.Z, terkait dengan solusi yang digunakan dalam meningkatkan konsistensi belajarnya yaitu: "ketika saya merasakan bahwa adanya kemalasan dalam belajar dan motivasi belajar yang tidak ada karena banyaknya pekerjaan ataupun akivitas yang saya kerjakan, maka hal yang saya lakukan melakukan intropeksi diri, dengan begitu saya akan menyadari kesalahan-kesalahan, dan ketika itu juga saya mulai mengontrol diri untuk tidak terjebak dalam zona ketidak peduliaan terhadap tugas-tugas perkuliahan, membagi waktu unutk selalu konsisiten dalam belajar di setiap harinya dengan jam-jam mengajar di sekolah."

Begitu ironisnya keadaan psikologis seseorang ketika motivasi belajar yang ada dalam dirinya itu tidak lagi nampak dengan berbagai kebiatan-kegiatan positif, banyaknya waktu yang terbuang akibat sia-sia sehingga sangat merugikan dan membuat seseorang akan mengalami kegagalan dan bisa berakibat hilangnya konsentrasi dalam pebelajaran. Oleh karena itu, selfcontrol merupakan sutau kondisi yang harus disadari seseorang ketika ingin mengukir berbagai prestasipretasi akademik. Tanpa adanya kesadaran dalam diri maka sulit bagi setiap individu untuk melakukan self control/ kontol diri dalam melakukan berbagai hal.

Dari berbagai fakta yang telah di ungkap, maka dapat dikatakan bahwa Kontrol diri atau Self control adalah bentuk keadaan mental sangat berpengaruh terhadap pembentukan tingkah laku setiap individu. Terwujudnya tingkah laku yang positif, baik, dan produktif akan berdampak hubungan baik dengan orang lain. Kemampuan kontrol diri sangat berpengaruh terhadap kebiasaan belajar yang benar, tingkah laku yang tertib dimasyarakat dan disekolah, kedisiplinan. Self control menduduki posisi paling penting yang harus dipahami dan diaktualisasikan oleh manusia. Hal ini disebabkan dengan meningkatnya arus globalisasi yang menuntun manusia untuk tetap berada dalam koridor pengontrolan diri sehingga mampu mewujudkan cita-cita yang ingin dicapai dan akan mengantarkan manusia pada titik kesuksesan.

\section{Simpulan dan Saran}

Dari berbabagai penjelasan di paragraf sebelumnya dapat penulis simpulkan bahwa dalam proses pembelajaran, baik formal maupun non forrmal sangat efesien ketika menerapkan konsistesi dalam belajar. Dengan diterapkannya konsistensi dalam proses belajar, maka dengan sendirinya kebiasaan akan terbentuk kemudian merasa gelisah apabila tidak belajar. Membangun konsistensi dalam belajar bukalanlah suatu perkara yang mudah, akan tetapi dibutuhkan kesiapan mental dalam menghadapi pengaruh-pengaruh negatif yang dapat mengganggu pembelajaran.

Konsistensi dalam belajar dapat di bentuk melalui kontrol diri (Selfcontrol), karena dengan adanya kontrol diri dan kesadaran akan menjadi media pengingat yang efektif dalam membentengi hal-hal yang dapat meruntuhkan konsistensi yang telah terbentuk. Hadirnya teori self control dalam membentuk konsistensi belajar diharapkan mampun menjadi media yang nantinya mengantar seseorang lebih giat dalam proses pembelajaran, baik pembelajaran formal maupun non formal.

\section{Daftar Rujukan}

Atosokhi Gea, Antonius. "Integritas Diri: Keunggulan Pribadi Tangguh", dalam Jurnal Character Building, Vol.3 No. 1, juli 2006.

Borba, Michael. Membangun Kecerdasan Moral : Tuju Kebijakan Utama Agar Anak Bermoral Tinggi. Jakarta: Gramedia Pustaka Utama, 2008.

Carlson, N.R. The Science of Behavior. Boston: Allyn dan Bacon, 1987.

Erma Suryani, Yulianda. "Kesulitan Belajar", dalam Jurnal Magistra, Vol. 22 No.73, September 2010.

Evertson.dkk, Manejemen Kelas Untuk Guru SD. Jakarta: Kencana, 2011.

Goleman, Daniel. Kecerdasan Emosi Untuk Mencapai Puncak Prestasi Working With Emosional Intelegence. Jakarta: Gramedia Pustaka Utama, 2005. 
KONSELING: Jurnal Ilmiah Bimbingan dan Konseling

Vol.1, No.1, Oktober 2019

Available online: https://journal.ilininstitute.com/konseling

Muhammad Fadhil Alghi Fari Majid, dkk

Hurlock, E.B. Psikologi Perkembangan Edisi 5. Jakarta: Erlangga, 1990.

J.P, Chaplin. Kamus lengkap Psikologi. Jakarta: Raja Grafindo Persada, 2008.

K.Basten, Shine: 5 Prinsip Untuk Membuat Usaha dan Karir Anda Melejit. Jakarta: Gunumg Mulia, 2010.

Mahmud, Psikologi Pendidikan, Bandung: Pustaka Setia, 2010.

Nashori, F. Agar Anak Anda Berprestasi, Yogyakarta: Pustaka Zeedny, 2011.

Nur Gufron dan Rini Risnawati, Teori-Teori Psikologi. Yogyakarta: Ar-Ruzz Media, 2011.

Robbins, S.P. Manajemen. Jakarta: Erlangga, 2010.

S.Khalsa. Pengajaran dan Disiplin Harga Diri. Jakarta: PT. Indeks, 2008.

Sriyanti, Lilik. "Pembentukan Self control dalam Perspektif Nilai Multikultural", dalam Jurnal Mudarrisa, Vol.4 No.1. Juni 2012.

Sugiyono, Metode Penelitian Kuantitatif Kualitatif dan R\&D, Bandung: Alfabet, 2017.

Ubaedi, N. 5 Jurus Menggapai Hidayah. Jakarta: Pustaka Qalami, 2005. 